\section{ÉPÍTÉSI BERUHÁZÁS TÁRGYÚ KÖZBESZERZÉSEK BIZTOSIITÁSI ELŐÍRÁSAI}

Soós Gábor (kiemelt biztositástechnikai szakértö, épités-és szerelésbiztositások, Generali Biztositó Zrt.), gabor.soos@generali.com

A cikk a Közbeszerzési Hatóság által kiadott Közbeszerzési Értesítő Plusz folyóirat 2019. 5. számában megjelent tanulmány változatlan formában történő utánközlése. Az eredeti cikk online elérhetö a Közbeszerzési Hatóság által fenntartott [https://ertesitoplusz.kozbeszerzes.hu/szam/20190515/epitesi-beruhazas-targyu-kozbeszerzesek-biztositasi-eloirasai/] weboldalon.

\section{ÖSSZEFOGLALÓ}

Az építés-szerelési biztosítások célja, hogy biztosítási fedezetet nyújtsanak egy építési projekt tartama során a kapcsolódó munkákra, gépekre, illetőleg felelősségi kockázatokra. Ez a biztosítási típus rendkívül összetett, és egyaránt igényli az építőipari és a biztosítási ismereteket. Rendkívül fontos, hogy a közbeszerzési kírások figyelembe vegyék a biztosításszakmai szempontokat annak érdekében, hogy az elvárások találkozzanak a biztosítási szektor által nyújtott szolgáltatásokkal. Jelen cikk az építés-szerelés biztosítások legfontosabb tudnivalóit foglalja össze, hogy ezzel is segítse annak megértését, hogy müködik ez a biztosítási típus.

\section{SUMMARY}

The construction insurance provides insurance coverage to the contractors and their related works, equipment and the third party liability during the period of building projects. This line of insurance can be very complex and requires expert who understand the building contractor business as well as the insurance industry. It is of vital importance that the public procurement tenders take into consideration the technicality of insurance industry, so the expectations could meet services offered by the insurance companies. The present article summarize the most important information on construction insurance in order to help us to understand how this line of business works.

Kulcsszavak: építés- és szerelésbiztosítás, közbeszerzés

Keywords: construction insurance, contractor's all risks insurance, C.A.R. insurance, public procurement

\section{JEL: G22, L74}

DOI: $10.18530 /$ BK.2019.4.88

http://dx.doi.org/10.18530/BK.2019.4.88
Köszönettel vettem a megkeresést a Közbeszerzési Hatóságtól, amikor e cikk megírására felkértek, hiszen folytatása lehet annak a közös munkának, amit évekkel ezelőtt indítottunk el a MABISZ-szal, és melyben azt a célt tűztük ki, hogy a közbeszerzéssel érintett építési beruházások kapcsán egyre szakmaibb kírások készüljenek, találkozzanak az elvárások a biztosítási szektor által nyújtható szolgáltatásokkal.

Egy ajánlatkérő távol áll a kivitelezők és tervezők mindennapos tevékenységétől, a kivitelezés kockázataitól.

Mivel a közbeszerzési rendszernek eredendően egy szigorú és kötött keretben kell jól működnie, az ajánlattevők érthető okokból minden elöírásnak próbálnak megfelelni, előre felkészülni, és ez már a pályázati szakasztól kezdve jelentős terhet ró a vállalkozásokra és egyben a biztosítási szektor szereplőire is, föleg ha egy nehezen érthető vagy éppen nem teljesíthető feltétellel találkozunk.

A MABISZközreműködésével készült szakmai útmutatók („A Közbeszerzések Tanácsának útmutatója az építési beruházások biztosítási követelményeiről”, ${ }^{1}$ valamint „A Közbeszerzések Tanácsának útmutatója az építési beruházásokhoz kapcsolódó projekt jellegü összkockázatú vagyon- és felelősségbiztosításokról”²) és a 2018. november 7-én megtartott szakmai nap is mind azt a célt hivatott szolgálni, hogy a biztosítások világába belátást engedjen a felelős akkreditált közbeszerzési szaktanácsadóknak, az edukációval emeljük a tudásszintet.

Személyes véleményem, hogy igazi áttörést egy központi szabályozással, egy normarendszer kialakításával lehetne elérni, mellyel helyükre kerülhetnének a dolgok, azaz milyen kockázatokkal lehet és kell számolni, azokra milyen megoldásokat lehet és érdemes elöírni, amiket aztán versenykorlátozás nélkül tudnak a biztosítók teljesíteni.

Nem egyszerủ a feladat, hiszen egy ajánlatkérő vagy annak megbízott közbeszerzési szaktanácsadója meglehetősen távol áll a kivitelezők és tervezők mindennapos tevékenységétől, a kivitelezés kockázataitól, és attól, hogy azokra milyen biztosításokat érdemes vagy kell kötni.

Jelen cikkben az építés- és szerelésbiztosításokkal és az általános felelősségbiztosításokkal foglalkozom mélyebben, bele nem értve a szakmai felelősségbiztosításokat, munkáltatói felelösségbiztosításokat, kezesi biztosításokat.

\section{Jogi keretek}

A jogi szabályozás rendkívül tömör [az építési beruházások, valamint az építési beruházásokhoz kapcsolódó tervezői és mérnöki szolgáltatások közbeszerzésének részletes szabályairól szóló 322/2015. (X. 30.) Korm. rendelet (a továbbiakban: 322/2015. (X. 30.) Korm. rendelet)], és csak felelősségbiztosítást vár el az Ajánlattevőktől, amit tekinthetünk úgy is, hogy a felmerülő kockázatok kezelését alapvetően az Ajánlattevőre hárítja át, csak a kockázatok egy szűkebb részére vár el kötelező megoldást, mivel nem kerül előírásra többek között a projektek vagyonbiztosításának szükségessége sem. 
A 322/2015. (X. 30.) Korm. rendelet 26. \$-a értelmében építési beruházás esetén az Ajánlattevő köteles - legkésőbb a szerződéskötés időpontjára - felelősségbiztosítási szerződést kötni vagy meglévő felelősségbiztosítását kiterjeszteni az ajánlatkérő által az eljárást megindító felhívásban vagy a közbeszerzési dokumentumokban elöírt mértékű és terjedelmű felelősségbiztosításra.

Az már komolyabb fejtörést okoz szinte minden biztosítási szakembernek, hogy az építési beruházásokra két önálló termékkör - azok saját feltételrendszerével, viszontbiztosítási hátterével - tud megoldást adni, ezek:

Általános felelősségbiztositások (és szakmai felelősségbiztosítások, pl. tervezői szakmai felelősségbiztosítás)

Építés- és szerelésbiztosítások - I. fejezet: vagyonbiztosítás, II. fejezet: felelősségbiztositás (jellemzően C.A.R., ritkábban E.A.R., de vannak már a magyar piacon még nem elérhető egyéb termékek, mint pl. CP Insurance, ezeken belül a fejezetek hasonló felépítésűek, a felosztás a nemzetközi szokványok szerinti szerződéses feltételrendszer tagolását követi).

A két termékkör között kiolvasható a közös halmaz, hiszen mindkettő tartalmaz felelősségbiztosítást, de míg az általános felelősségbiztosítások alapvetően csak felelősségi károkra nyújtanak széles körű védelmet, határozatlan időtartamra, ritkán nevesítve egy-egy projektre, addig az építés- és szerelésbiztosításoknál a hangsúly a vagyonbiztosítási fedezeten van, anélkül az nem is köthetö, és jellemzően projektbiztosításokat tartalmaznak, még akkor is, ha egy keretszerződésről beszélünk, ami több határozott idejű projekt gyűjtőszerződése.

A törvényi szabályozás csak felelősségbiztosítást ír elő, a biztosítási szektor a nemzetközi gyakorlat szerint pedig az építési beruházásokra elsődlegesen az építés- és szerelésbiztosításokat tudja nyújtani, így már az elején elcsúsznak egymástól az igény és a lehetőségek.

\section{Felelősségbiztosítási összeg, kártérítési limit}

A felelősségbiztositások esetében a biztositási szolgáltatás mértékének meghatározásához biztositási összeget vagy kártéritési limitet használnak a biztositók (továbbiakban: limit).

Jellemző, hogy az általános felelősségbiztosításoknál - mivel azok határozatlan időre szólnak, egyéves biztosítási időszakkal - káreseményenkénti és éves limitet használnak, és ez a szerkezet átkerült a kiírásokba is. Az építési projektekre szóló építés- és szerelésbiztosításoknál viszont szinte értelmezhetetlen az éves limit elöírása, hiszen itt pár hónapos szerződésektől kezdve több éves kivitelezések is elképzelhetőek.

Ha kisebb a kivitelezési időszak, mint egy év, akkor vajon mire jó az éves limit, ha hosszabb, akkor miért kellene évente limitálni a felelősségbiztosítási limitet.

A projektekre szóló építés- és szerelésbiztosításokban (egyedi szerződések) a felelősségi limitet káreseményenként, valamint a kivitelezés teljes időtartamára határozzuk meg.

Viszont találkozhatunk nem is egyszer éves limittel az építési és szerelésbiztosításoknál is, ugyanis keretszerződéseknél éves limitet használunk, mivel a keretszerződések, hasonlóan az általános felelősségbiztosításokhoz, egy évre szóló biztosítási szerződések, ahol évfordulók között egy teljes év a biztosítási időszak. Így lehet, hogy sok esetben a keretszerződések miatt az éves limit előírásának megfelel az építés- és szerelésbiztosítási szerződés, de egyedi szerződéseknél az éves limit nem igazán értelmezhető.

\section{Projektbiztosítás és általános felelősségbiztosítás}

Az építés- és szerelésbiztosítás alapvetően egy projektre létrejött kvázi ernyőbiztosítás, ahol a sok szereplő, köztük a Megrendelő, Fővállalkozó/Generálkivitelező, alvállalkozók, a meglévő és szomszédos vagyontárgyak, az építési eszközök a munka kezdetétől a végéig biztosítási fedezet alatt állnak.

\section{Az építés- és szerelésbiztosítás alapvetően egy projektre létrejött kvázi ernyőbiztosítás.}

Az általános felelösségbiztosítások viszont alapvetően nem egy építési projektet, hanem egy biztosítottat hivatottak védeni.

Az épitési projektekre elvárható és szükséges, hogy legyen egy teljes körü fedezet, és ugyanúgy elvárható a kivitelezési és szakmai munkát végző vállalkozásoktól, hogy legyen egy folyamatosan fennálló általános felelősségbiztositásuk.

Ugyan a biztosítási szakma és a gyakorlat sem teljesen egységes, de véleményem szerint egy projektbiztosításnak a helyes felépítése az, ha a Fővállalkozó/Generálkivitelező, esetleg a Megrendelö köt egy építés- és szerelésbiztositást, mely minden szereplőre kiterjed, az alvállalkozók (kivitelezők, tervezők, beszállítók) pedig határozatlan időtartamú általános, vagy szakmai, vagy termékfelelősség-biztosításokkal védhetik magukat, így porlasztva a kockázatot.

\section{Kritikus kockázatok}

A Kodály köröndi palota tűzkárából sokat lehet tanulni, hiszen egy kis építési/karbantartási munkából eredő, léptékében óriási, milliárdos kár képes arra, hogy emberek tucatjainak életét egy pillanat alatt tönkretegye. A kivitelezők, még ha rendelkeznek is általános felelősségbiztosítással, az a piacon elérhető limitekkel meg sem közelítheti a lehetséges károkozás mértékét, de az is igaz, hogy bármekkora limitet kötnek, annál mindig lehet nagyobb kár, mégis valamilyen észszerű szinten meg kell húzni a biztosítási fedezet határát.

Érdemes számításba venni, hogy a belátható kockázatokon felül és bizonyos kármérték felett az állam - beleértve az önkormányzatokat is - már aktívan meg fog jelenni, és bele fog avatkozni a kár rendezésébe, a károsultak megsegítésébe. Ahogy a vörösiszap-katasztrófa is jól mutatja, a vállalkozás kárára az állam megtérítési igénnyel is élhet, természetesen ez csak azoknál a vállalkozásoknál lehetséges, ahol erre a törvényi kereteken túl vagyoni fedezet is van. 
A társasház-biztositásoknál - de általánosságban is igaz a vagyonbiztosításoknál - az építési munkából eredő károk kizárásra kerülnek, de annak nincs akadálya, hogy a kivitelező rendelkezzen olyan építés- és szerelésbiztosítási szerződéssel, ahol az építtető/megrendelő meglévő tulajdonára is kiterjeszthető a fedezet a kivitelezéssel okozott károkra.

Nagyon fontos kiemelni, hogy pusztán a felelősségbiztosítási fedezet sem az általános felelősségbiztosításnál, sem az építés- és szerelésbiztositás felelősségbiztosítási részénél nem tud fedezetet adni a megrendelő meglévő vagyontárgyaiban okozott károkra, ezekre külön fedezet kiterjesztés szükséges.

Az általános felelősségbiztosításoknál a szolgáltatói felelősségbiztositás kiterjesztés, az építés- és szerelésbiztosításnál a fent említett építtető/megrendelő tulajdon kiterjesztés adhat fedezetet.

A Notre-Dame székesegyháznak a felújitása alatt nemrég bekövetkezett tűzkára ugyanezeket a fenti kérdéseket veti fel. Ezek az esetek bár katasztrofálisak, de ha levonjuk belölük a megfelelő konzekvenciákat, akkor könnyebben felkészülhetünk a jövőben a hasonló esetekre, és ez nemcsak a biztosításokra igaz, hanem az építési munkálatok alatti kármegelőző intézkedésekre is.

\section{Milyen kockázatokra keressünk fedezetet?}

A kiírásoknál gyakran találkozunk azzal, hogy csak egy bizonyos, például 10 százalékos önrészt határoznak meg, ami sajnos értelmezhetetlenné teszi a kockázatvállalást, hiszen nagyon kis kárt is rendezni kellene, ahol a kárrendezés költsége többszöröse lesz a kár mértékének. Ugyanakkor egy nagyon nagy kár esetén a 10 százalék már komoly tétel is lehet.

Az ajánlatkérő szempontjából mit érdemes végiggondolni?

Kiemelten fontos: Építtetö/Megrendelő és a projekt védelme.

Kevésbé fontos: Ajánlattevő (és építési szereplők) összes kockázatainak kezelése.

Óriási adminisztrációs teher az építőgépek, építési eszközök projektenkénti nyomon követése.

A Megrendelő szempontjából kritikus kérdés, hogy a beruházás határidőre, a műszaki előírásoknak megfelelően és I. osztályú minőségben készüljön el. Egy kisebb kár (akár pár milliós összeghatárig) biztosan nem fogja a kivitelezést megakasztani vagy meghiúsítani, de egy nagyobb kártétel esetén ajánlattevőként a Szerződő Félnél cash-flow probléma keletkezhet (nincs elég forgótőke vagy forgóeszközhitel a kár helyreállítására), vagy éppen az, hogy nem tudja a veszteséget a projektre tervezett tartalékból, nyereségből vagy még rosszabb esetben saját tőkéjéből finanszírozni, ami akár a vállalkozás csődjéhez is vezethet.

Ezekben az esetekben a projekt leállásából, a megvalósítás időbeli csúszásából, az Ajánlattevő vállalkozás ellehetetlenüléséből, esetleg kivitelezőváltásból eredő vagyoni károk oly nagymértékűek lehetnek, amit nehéz belátni, de elkerülésük mindenképpen kiemelten fontos.
Építtető/Megrendelő szempontjából az a kérdés, hogy a munkálatok helyszínén az alvállalkozói lánc valamelyik szereplőjének építőgépe biztosítva van-e, vagy ha bérbe vették, akkor a bérbeadó biztosította-e már, kevésbé releváns. Jellemző, hogy a vállalkozási szerződés aláírásakor még aligha tudják beazonosítható módon a biztosításba feladni, fedezet alá vonni az eszközeiket.

Az egyik közbeszerzési előírás tartalmazta az építőgépek biztosítását is, legalább $100 \mathrm{M} \mathrm{Ft}$ erejéig, és csak többszöri egyeztetés után derült ki, hogy nem is lesz a kivitelezőnek építögépe a helyszínen. Mivel nem volt más lehetőség, végül az Ajánlattevő megfizette az építőgépek biztosításának díját is.

Mivel óriási adminisztrációs teher az építőgépek, építési eszközök projektenkénti nyomon követése, vagyonbiztosítási fedezetet a biztosítási szektor nem is tud adni elsőkockázati összegre (limitbiztosítás) úgy, hogy nincs tételes beazonosítható géplista, ezért érdemes átgondolni, hogy csak általánosan legyen elöírva az eszközök biztosítása, értékmegnevezés nélkül, így a kivitelezők, tulajdonosok szabadon dönthetnek, hogy hol és milyen biztosítási fedezetet kötnek. Ha viszont egy nagyon jelentős értékű gépről van szó, például egy vasúti vágányokat átépítő gépről, ott már érdemes a biztosítási fedezetet ellenőrizni, vagy akár elöírni a fedezetet rá.

\section{Kármegelőzés, kockázatok kerülése}

A biztosítások ott működnek igazán jól, ahol a biztosítottak alapvetően kerülik a kockázatokat, előre gondolkodnak, a kárveszélyt kármegelőzési intézkedésekkel csökkentik, hiszen minden intézkedésre fordított összeg jellemzően töredéke a tényleges kár helyreállítási költségének. A kármegelőzés költsége minden esetben a biztosítottat terheli.

Érdekes a helyzet a meglévő épületek (kastélyok, templomok vagy új funkciót kapó régi épületek) felújításával, átalakításával kapcsolatos beruházásoknál, ahol a meglévő tetőszerkezet, a héjalás vagy vízszigetelés megbontásra kerül, vagy a vízelvezetést nem oldják meg, és ha jön az eső - ami általában jön -, megtörténik a beázás, a kár. Sokszor műszakilag nem is megoldható, vagy oly költséges lehet ideiglenes tetőt készíteni, hogy a vállalkozók ezt megspórolják, és inkább az - esetleges - beázással okozott károkat kijavítják. Ez lehet akár teljesen racionális döntés is részükről, ha a bekövetkező kár előreláthatóan kisebb, mint az azt elhárítani hivatott kármegelőzés költsége, vagy ha amúgy is tervezetten felújításra kerül az épület többi része is.

Ennek is köszönhető, hogy leggyakrabban a beázásokkal kapcsolatos kockázatokat a biztosítók kizárják vagy limitálják, esetleg próbálják többféle elöírással kezelni a kockázatot, de a biztosítási szakemberek nem kivitelezők, nem lehetnek ott folyamatosan a beruházásoknál, és nem végezhetnek költség-haszon elemzéseket sem.

Az építtető a kockázatokat jellemzően áttelepíti a vállalkozókra, akiknek így a kockázattal mint bizonytalansági tényezővel és költséggel számolniuk kell, legyen az árvíz vagy belvíz kockázat, vagy az, ha előre nem látják, hogy milyen altalajjal fog a kivitelezésnél 
találkozni, vagy az, ha a tervezett szennyvíztelep kibocsátása nem hozza az elvárt szinteket. A kockázat a vállalkozási költségeket drasztikusan emeli, viszont ezeket a kérdéseket önmagában biztosítással nem lehet kezelni.

Az építtető/megrendelő már a munkálatok megrendelése előtt dönthet arról, hogy a kármegelőzési intézkedéseket a projekt megvalósításába beépíti-e, a vonatkozó költségkeretet hajlandó-e finanszírozni, vagy sem

\section{Szavatossági fedezet/jótállás}

A felelősségbiztosítás jótállási időszakra való kiterjesztése sajnos alapvető problémát jelent, mert az építés- és szerelésbiztositások alapfedezete az átadással véget ér, így megszünik a felelösségbiztosítási fedezet is.

Bár lehetséges az építés- és szerelésbiztositások kiterjesztése a szavatossági fedezet záradékokkal (C.A.R. és E.A.R. feltételek 003. és 004. záradék) az átadást követő időszakra, de egyrészt itt csak bizonyos kockázatok kezelése megoldható, azaz a garanciális munkákkal okozott vagy az átadást megelőző kivitelezési hibából eredő károkra, de csak azon vagyontárgyakban okozottakra, melyek a biztosított építési teljesítés részei voltak. Tehát nem beszélhetünk valódi felelősségbiztositási kiterjesztésről vagy esetleg termékfelelősség-biztosításról, aminek egyébként értelmezni lehetne a kiírásokat.

Biztosítási fedezet nem adható a vállalkozók jótállási kötelezettségére, ezekre legfeljebb bankgarancia vagy kezesi biztosítás köthető szavatossági/jótállási kötelezvénnyel.

\section{Tervezési hibákból eredő károk}

A tervezési tevékenységre vonatkozóan külön köthető tervezői szakmai felelősségbiztosítás is, ami az építés- és szerelésbiztosításokhoz képest szélesebb fedezeti körrel, de alacsonyabb limitekkel, azáltalános felelősségbiztosításhoz hasonlóan működik. Ez viszont nem összekeverendő az építés- és szerelésbiztosítás 115. tervezői kockázat záradékával (ami egy vagyonbiztosítási kiterjesztés, a C.A.R. feltételek záradéka), ahol csak azok a károk téríthetőek, melyek tervezői hibából a jól kivitelezett építési részekben hirtelen, balesetszerű események következtében keletkeznek a kivitelezési időszakban.

\section{A jó szándékú, de szakmailag hibás kiírások nagyon \\ sok problémát okoznak.}

\section{Kiírások értelmezése}

Ahogy fent is látható, az építési projektek és azok kockázatainak széles spektruma, a projektek megvalósításában részt vevők nagy száma és érdeke, a biztosítható vagyontárgyak sokasága megkeverve az elérhető biztosítási termékek körével igazán komplex terület.
A jó szándékú, de szakmailag hibás kírások nagyon sok problémát okoznak, gyakran egyáltalán nem is értelmezhető, mit szeretne a kíró, vagy teljesíthetetlenek a feltételek, aminek következményei akár nagyon súlyosak lehetnek.

Betühiba:

Nem egyszer fordult már elö, hogy megkötött E.A.R. szerződést (szerelésbiztosítás) törölni kellett, és egy új C.A.R. biztosítást kellett kötni, mivel a kiírásban nevesítetten C.A.R. szó szerepelt. Fedezeti szempontból az E.A.R szerződés jobban megfelelt volna az ügyfélnek és a projekt biztosításának, de a közbeszerzési rendszer kötöttsége miatt ragaszkodtak a szó használatához, betücseréhez, természetesen azonban ez így nem megoldható.

\section{Javaslatok}

A piacon elérhető korlátozott szakmai információk és a terület összetettsége miatt az alábbiakat javasolnám az elöírások megalkotásánál:

Mabisz szakmai útmutatók áttanulmányozása,

Kritikus nagy kockázatok felismerése,

Túlszabályozás kerülése, csak a feltétlen szükséges biztosítási fedezeteket írjuk elő,

Egyszerü és szakmai zsargonban megszokott megfogalmazások használata,

Adminisztráció csökkentése, szándéknyilatkozatokat továbbra is mellőzni, a biztosítási fedezetek igazolására rugalmasabb időkeretet megadni, nem hozzákötni a vállalkozási szerződés aláírásának dátumához.

Összefoglalva azt tanácsolnám, hogy történjen meg a jogszabályi előírásnak megfelelö felelősségbiztosítási fedezet, valamint az építési teljesítésre vonatkozó vagyonbiztositási fedezet elöírása a vállalkozási szerződésben meghatározott építési időszakra, káreseményenkénti limittel és teljes limittel, ahol a teljes limit lehet éves vagy időszaki limit is.

Ajánlott, hogy a káreseményenkénti limit 2-3-szorosa legyen a teljes limit (projektmérettől, kockázattól és időszaktól függően), ez is lényegesen több, mint amire a tapasztalatok alapján szükség lehet.

Amennyiben tervezési tevékenység is a feladat része, úgy tervezői szakmai felelősségbiztosítást is javasolt elöírni a fentiekhez képest kisebb limittel, itt természetesen lehet a szokásos káreseményenkénti és éves limitet elvárni.

\section{Amit érdemes lehet mindenképp megfontolni az építés- és szerelésbiztosításon beliil}

- Ha van olyan, az Építtető vagy Megrendelő tulajdonában álló meglévő épület, amin vagy amely mellett dolgoznak, akkor a meglévő épületre vonatkozó kiterjesztéssel.

- Jótállási időszakra lehetőleg 36, de max. 60 hónapos időszakra előírni a fedezetet. Az első 36 hónapra a kiterjesztett szavatossági fedezet záradék (C.A.R. vagy E.A.R. feltételek 004. záradéka), ezen túl már csak a szavatossági fedezet záradék (C.A.R. vagy E.A.R. feltételek 003. záradéka) nyúithat megoldást további 24 hónapra. 
- Tervezői kockázatra is kiterjeszteni a fedezetet, a tervezői szakmai felelősségi limitnél magasabb értékre.

- Többletköltségekre vonatkozó fedezetet elöírni, max. az adott projekt értékének 5-10 százalékára.

\section{Limitösszegek meghatározása}

A felelősségi limitek meghatározása - és ez igaz az Építtető/Megrendelő tulajdonában álló meglévő épület értékének a limit biztosítására is - az egyik legnehezebb eldöntendő kérdés.

Amíg nincs biztosítási esemény, addig a legtöbb ügyfél úgy tekint a biztosításra, mint kidobott pénz, a magasabb limitek pedig magasabb dijakat is eredményeznek. Egy kisvállalkozásnak egy kisebb limit megvásárlása is sokba kerül, míg egy több milliárd eurós árbevételű multinacionális vállalat esetében ez elhanyagolható mértékű kérdés lehet - de mit is várjunk el?

\section{A felelösségi limitek meghatározása az egyik legnehezebb} eldöntendö kérdés.

Érdemes a kockázatra úgy tekinteni, ahogy a biztosítók, azaz megbecsülni a kockázatot, annak valószínűségét, a várható legnagyobb káreseményt, és abból kiindulva lehet meghatározni egy minimum elégséges felelősségi limit szintet is. Magáról az építési teljesítésről mint vagyonbiztosítási fedezetről most nem kell beszélnünk, arra, ha kötnek építés- és szerelésbiztosítást, akkor a teljes összeg erejéig a biztosító helytáll.

Egy lakott terület szélén lévő zöldmezős, új épület építése esetén értelemszerűen elenyésző az esélye, hogy harmadik személyeknek felelősségi kárt okozzon a vállalkozó, míg egy nagy forgalmú belvárosi épület rehabilitációja esetében a kár valószínűsége nagyságrendekkel nagyobb. Értelemszerüen az utóbbi esetben számolni kell egy épületrész- vagy állványomlással, tűzkárral, ami átterjedhet a környezö épületekre, így ezen esetekben a több százmillió forintos nagyságrendủ limitnek is helye és szerepe van. Ugyanez igaz a meglévő épületben a kivitelezés által okozott károkra is, szintén érdemes megbecsülni a meglévő épület újraépítési értékét és az esetlegesen bekövetkezhető kár mértékét, hogy annak megfelelő limitértéket lehessen előírni.

\section{Kiegészítő fedezetek}

Jelen cikkben nem érintettük, de az általános felelősségbiztositáson és építés- és szerelésbiztosításon túl a piaci szereplők a következő termékeket használják még a kockázataik kezelésére, ezek közül a kezesi biztosítások már a mindennapok részei:

- Munkáltatói felelősségbiztosítások

- Balesetbiztosítások

- Bankgarancia és/vagy kezesi biztosítások

- Gépbiztosítások.

\section{Összegzés}

Olyan biztosítási fedezetet, amely minden veszélyre megoldást nyúit, legyen az műszaki, természeti, emberi, politikai vagy gazdasági kockázat, biztosan nem lehet adni, de amennyiben körültekintően járunk el, úgy a nagyobb kockázatokra vonatkozó biztosítási fedezetek rendben lesznek, a projekt és annak megvalósulása biztosítva lesz, továbbá a vállalkozások olyan megoldásokat fognak keresni, amilyeneket a biztosítók lehetőségeikhez képest, az ügyfeleik megelégedésére nyújtani tudnak.

\section{HIVATKOZÁSOK}

'A Közbeszerzések Tanácsának útmutatója az épitési beruházások biztositási követelményeiről (KÉ 2018. évi 80. szám). ${ }^{2} \mathrm{~A}$ Közbeszerzések Tanácsának útmutatója az építési beruházásokhoz kapcsolódó, projektjellegü összkockázatú vagyon-és felelősségbiztositásokról (KÉ 2018. évi 80. szám).

\section{FORRÁSOK}

322/2015. (X. 30.) Korm. rendelet azépitési beruházások, valamint azépitési beruházásokhoz kapcsolódó tervezőiés mérnöki szolgáltatások közbeszerzésének részletes szabályairól

2018. április 25) https:/wwwk utmutatója az épitési beruházások biztositási követelményeiröl (KÉ 2018. évi 80. szám, letöltés idő̉pontja: A Közbeszerzések Tanácsának útmutatója azépitési beruházásokhoz kapcsolódó projektjellegủ összkockázatú vagyon-és felelóssségbiztosításokról (KÉ 2018. évi 80. szám, letöltés időpontja: 2018. április 25.).

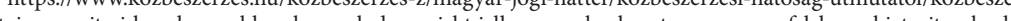

